\title{
咽喉頭異常感症の上咽頭粘膜血流量
}

\author{
山下 利幸・山口 幹夫・石谷 保夫
}

\section{Effect of Local Hyperthermia on}

\author{
Abnormal Sensation in the Throat
}

\section{Toshiyuki Yamashita, Mikio Yamaguchi and Yasuo Ishitani \\ (The University of Tokushima School of Medicine)}

We examined the effects of local hyperthermia by humidified aerosol at $43^{\circ} \mathrm{C}$ on blood flow in the epipharynx using a spectrum analyzer. We measured the blood flow in patients with epipharyngitis, abnormal sensation in the throat, before and after nasal hyperthermia, as well as in healthy subjects.

Epipharynx blood flow was high in the epipharyngitis group, and was decreased by local hyperthermia. Local hyperthermia normalized epipharynx blood flow in the group with abnormal sensation in the throat. In some patients abnormal sensation in the throat disappeared or decreased after local hyperthermia; therefore, this treatment appears to be useful.

Key words: local hyperthermia, epipharyngitis, abnormal sensation in the throat

\section{はじめに}

咽喉頭異常感症の原因として，精神的要因， 全身的要因, 局所的要因が举げられる が, 局 所的要因の中には，軽微な炎症に起因するもの あ少なくない.しかし, 従来の視彭による診断 では炎症の程度を定量化することは困難であ る. 組織スペクトル分析器は粘膜下の血流量を 定量的に测定することができ ${ }^{2)}$ ，局所の炎症の 程度を定量化できる可能性があるものと思われ る.

一J, 桨物を一切用いず, 浆留水のエアロゾ ルを使用する局所温熱エアロゾル療法は, 最近 鼻アレルギーや感冒初期の鼻炎症例に刘する新 しい治療方法として注目されている374.

今回我々は, 上咽頭炎症例, 咽喉䫓異常感症
例，正常例に対し，組織スペクトル分析器を用 い，それらの上咽頭後壁の粘膜血流量を测定 し，疾患群の間でのIIII流状態の善を調べ更に経 鼻的に局所温熱エアロゾル療法を試み粘膜血流 の面から見たてれらの疾患の病態に関し興味あ る知見を得たので報告する.

\section{対象亡方法}

詔和61年に当科栶喉頭異常感症外来を訪孔た 咽唤櫬黑常感症例 12 人, 上咽頭炎症例 4 人, 対 照 5 人を検祈刘象とした.

検查は 1) 住友笔工社製組織スペクトル分 析装算T S - 200，2）ミドリ努全社製局所温 䓡エアロゾル装监（Rhinotherm）を用いて行 った。

1. 府所潜熱療法前の血流星测定：対象者に 
対し左鼻控より軟性ファイバースコープを插入 し，上咽頭を可視下に拈いた，次いで右鼻腔よ り綿棒を用いて上咽頭後壁にピオクタニン色素 を付着させた．ピオクタニン色素付着点を指標 として，てれと少し離れたところに組織スペク トル分析装置のプローブの先端を接触させ，同 部位の血流量を測定した。

2. 局所温熱療法後の血流量測定 : 同じ対象 者に対し, 経鼻的に $42^{\circ} \mathrm{C}$ 加温加湿されたエア ロゾルを局所温熱療法装置によって約15分間送 り込んだ。そして再度同じ方法によりピオクタ ニン色素付着点を指㯹として上咽頭粘膜血流量 を测定した。

図 1 に示したものが, 組織スペクトル分析装 置 T S - 200 で, 光ファイバーを用いて白色光 を照射し, 組織の反射光を分析し, 吸収スペク トルを測定するものである2).

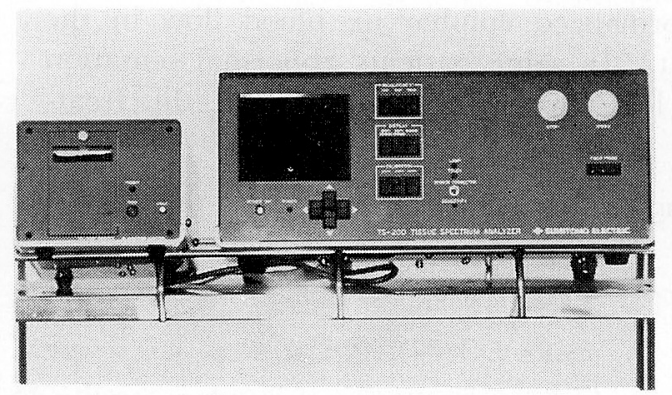

図｜組織スペクトル分析装置T S-200
使用したファイバーの直径は約 $2 \mathrm{~mm}$ で, フ アイバー先端にはプローブが付いている（図 2 ).

図 3 には局听温熱エアロゾル療法装置の本体 を示した。 5〜10 $\mu \mathrm{m}$ の練かい霧状の水滴が発 生し， $43^{\circ} \mathrm{C}$ 亿温められた湿気を含んだ空気が直 接鼻腔内に入る ${ }^{4)}$.

\section{結 果}

1. 咽喉頭異常感症例の上咽頭粘膜血流量之 温熱療法の効果

図 4 はある咽喉頭異常感症患者の局所温熱療 法施行前の上咽頭粘膜血流の測定結果である. 横軸に時間，縦軸に测定值を示した。 $\mathrm{I}_{\mathrm{so} 2}=$ 38, I $\mathrm{I}_{\mathrm{Hb}}=60$, の值が得られたが， I so $2_{2}$ は組 織血管内の $\mathrm{Hb}$ の酸素飽和度を表わすパラメ

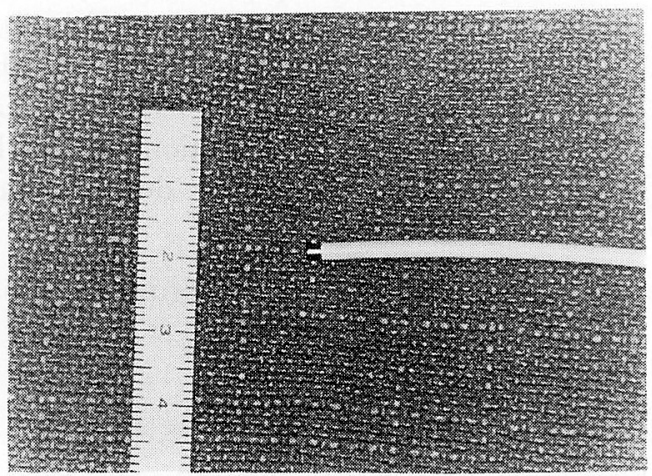

図2 光ファイバー

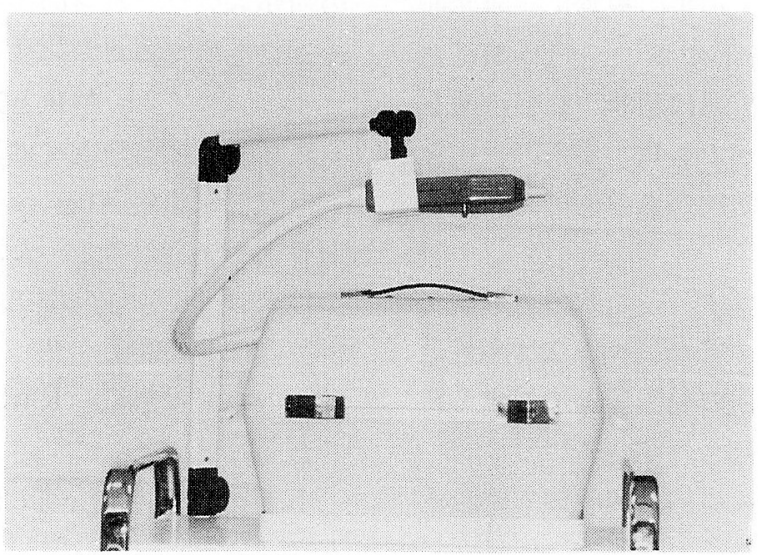

図 3 局所温熱エアロゾル療法装置 
ーターであり， I нь 值は組織IIII管内の $\mathrm{Hb}$ 旦 を表わすパラメーターである. IIII流是の絶対値 を示すむのではないが，組織IIII流量と相関する 值であると言われている2).

図 5 に同一者の局所温熱療法後の测定結果を 示した． I so2 は37であり, 前值と比較して变 化はないが， I нь 前值60から86に上昇してい る. 図 6 に図 4 と図 5 をまとめたが，乙れによ り任流量の増加が明らかである。

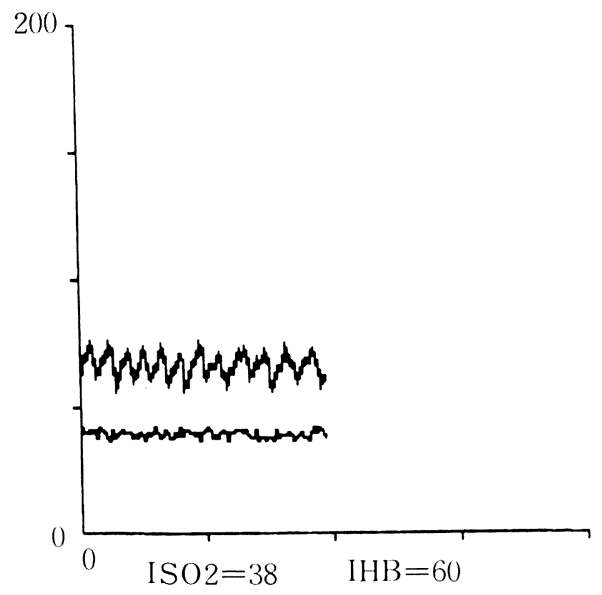

図 4 局所埧熱燎法前の I $\mathrm{Hb}$ 值

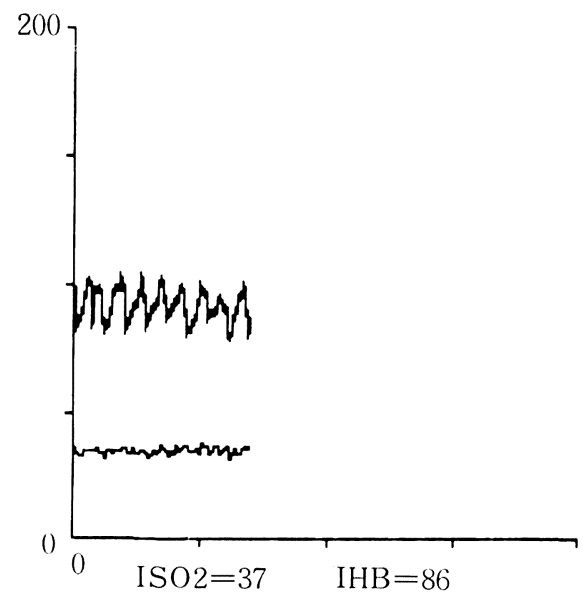

図 5 局所温熱獠法後の IHb 倬

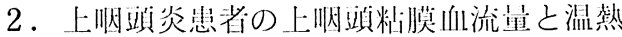
療法の効果

後鼻鏡またはファイバースコープにより上顺 䫓に発赤を認める隹者に対して上咽頭料膜のIIIl 流星を测定した。I нь は150〜200であり局闩 温䓡療法を施すことにより，全例 I Ho 值の低 下をみた。

栶焕頭異常感症，上栶頭炎，正常群での血流 星测定值を図 7 に示した。黑丸は局所温熱療法 施行前の测定值であり，温熱療法による測定值 の变化を知印で示した。肉眼的に高度の発赤を 認めた上眭韻炎での!III流量は他の 2 群に比較し

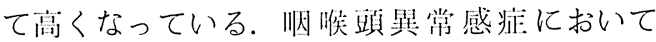
I нь 前值は正常潞と変わらない分布を示して いるが，前优が分优の中でも低いものは温熱痖 法後值が上昇し，前值が高いものは後值が低下 する傾向にある。

表 1 亿局所温熱䝤法前後の I нь $の$ 平均值之 槛淮偏差を示した。施行前後のIIII流旦の変化の

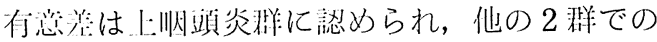
暗は有意ではなかった。

考按

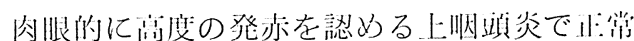

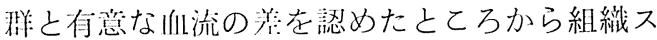

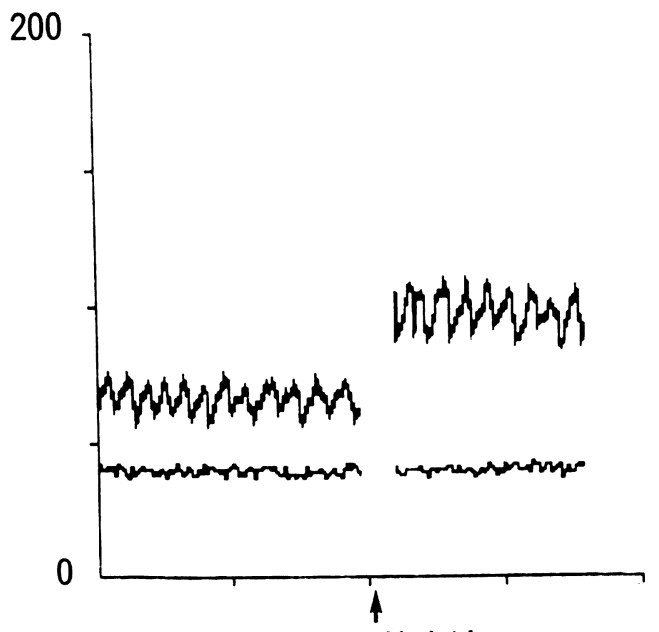

局所温熱療法

図 6 局阶温熱燃法前後での $\mathrm{I}_{\mathrm{IIb}}$ 值の変化 


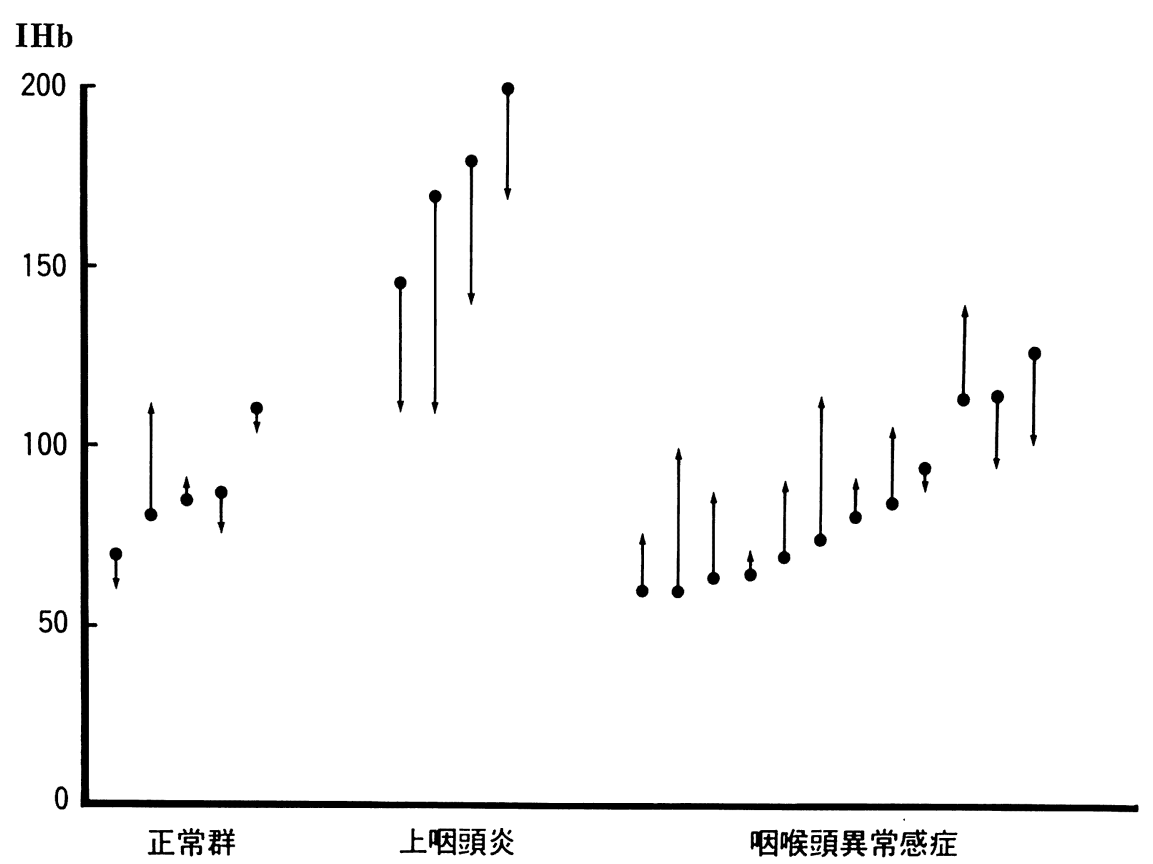

図 7 各聅想群での局所温熱療法による $\mathrm{I}_{\mathrm{Hb}}$ 值の変化

表। 各疾患群での局所温熱燎法前後での $\mathrm{I}_{\mathrm{Hb}}$ 平均值之標準偏差

\begin{tabular}{|cc|c|c|c|}
\hline & & 正 常 & 上咽頭炎 & 咽喉頭異常感症 \\
前 & 值 & $87 \pm 14.7$ & $174 \pm 22.4$ & $84.8 \pm 24.0$ \\
\hline 後 & 值 & $88.4 \pm 21.2$ & $132 \pm 27.9$ & $97.2 \pm 18.4$ \\
\hline
\end{tabular}

ペクトル分析装置は局所の!II流显により炎症の 程度を定量化でき，血流の变化を客微的に捉え るととが考えられた。また咽㗹頭異常感症12例 で局所温熱療法後異常感が消失したものや，異 常感評価スコアー ${ }^{5)}$ が改善する例も見られ，局 淅温熱療法は薬剤を用いない新しい理学的療法 としての有効性, 有用性が期街できると思われ た. また有効例では療法前值が低下しているも のが多く, 粘膜血流星の低下が異常感発現の要 因となっていることが想像された。咽吹頭異常 感症に対し局所温熱療法はIIII流显の少ないもの は增加させ, 血流量の多い屯のは低下させる傾 向にあり，一定の粘膜血流量の正常域内に戻さ せる効果があるのではないかと思われた。

\section{まとめ}

上呕㣀粘脱 III流星测定により以下の結果が得 られた。

1.上咽竨炎の症例における咽頭後壁粘膜の 血流量は増玑しており, 局所温熱療法により減 少した。

2. 咽知䫓異常感症に対し局所温熱療法を施 行した場合, IIIl流量の少ない場合は増加させ, I III流量の多い埸合は低下させる傾向にあった。

3. 局所温熱療法前後で異常感評価スコアー が改善するすのや，異常感が消失する屯のがあ り, 治療法としての有用性, 有効性が期待でき た。

4. 組織スペクトル分析装置は炎症の程度を 片流星に上り定旦化し，客観的に捉えるために 利用しうると思われた。

稿を終えるにあたり, 御校閲, 御指導を睗った小池 靖夫教授に深謝致します。 


\section{参考文献}

1) 小池靖夫, 他: 咽喉頭異常感症に対する彰断的治 療. 耳鼻臨床 $72: 1499 \sim 1506$.

2) 平本順一, 神田昌彦: 医療用組織スペクトル分析 装置. レーザー研究 13:165〜170, 1985.

3) Yerusharmi A, et al : Proc Natl Acad Sci USA $79: 4766 \sim 4769,1982$.

4) 橋本真実, 他：上気道粘膜に対する局所温熱
の影響. Therapeutic Research $3: 52 \sim 59$, 1985.

5 ）小池靖夫：咽喉頭異常感症の数量化に関すを研 究. 昭和161年度科学研究費補助金研究成果報告書 (研究課題番号：60570812） $1 \sim 8,1987$.

$$
\left(\begin{array}{l}
\text { 別刷請求先: 山下利幸 } \\
\text { T770 徳島県徳島市蔵本町 } 3 \\
\text { 徳島大学医学部耳鼻咽喉科学教室 }
\end{array}\right)
$$

